\title{
DILEMMAS AND ADVANCES IN POST-CONFLICT IN COLOMBIA: A LOOK FROM THE SUBALTERN PERSPECTIVE OF PEACE (S) IN THE TERRITORIES*
}

\author{
Eduardo Andrés Sandoval Forero** \\ https://orcid.org/0000-0003-1659-7588 \\ José Javier Capera Figueroa*** \\ https://orcid.org/0000-0003-1823-2814
}

\section{RECIBIDO: Febrero 2020 / ACEPTADO: Marzo 2020 / PUBLICADO: Mayo 2020}

Como citar: Sandoval Forero, Eduardo; Capera Figueroa, José (2020). Dilemmas and advances in post-conflict in colombia: a look from the subaltern perspective of peace (s) in the territories. Telos: revista de Estudios Interdisciplinarios en Ciencias Sociales, 22 (2), Venezuela. (Pp.387-394).

DOI: www.doi.org/10.36390/telos222.10

\section{ABSTRACT}

The emergence of building a popular culture, based on the ethical-political imperative that links the demands, needs and struggles of those below, constitutes an aspect that configures the dynamics of re-existence of social groups in their different realities. On reflection of this is the peace process signed between the Farc-Ep guerrilla group / party and the Colombian government. Thus, the objective of the following article is to conduct a theoretical-conceptual discussion about the dilemmas and advances that coexist in the Colombian post-conflict, from a subaltern perspective of peace (ces) in the territories, taking into account the proposals theoreticians of peace scholars like Alonso (2013); Márquez Fernández, Á. (2018a) , who consider the need to question from a critical perspective the dynamics of peace (s), created in the territories. The methodology used was collaborative research and critical discourse analysis (Sandoval, 2016a), which starts from generating an intersubjective and horizontal dialogue between the researcher and the social groups. The fundamental conclusion of the investigation was the need to recognize the subject's praxis and his political ethos in terms of building laboratories, spaces and territories of peace from and with those below, that give weight to the logic of violence promoted and exerted from the hegemonic groups in the regions.

* Document prepared for the II Itinerant Chair of Philosophy - Unad (Colombia). I am grateful for the invitation made by Master Andrea del Pilar Arenas (Unad- Ibagué). Likewise, the revision of style of the literary Indira Enriquez and the translation of the English graduate Robinson Ospino.

** Doctor in Sociology, National Autonomous University of Mexico. Master in Latin American Studies, Autonomous University of the State of Mexico, and Social Anthropologist, National School of Anthropology and History (Mexico). Member of the National System of Researchers of Mexico, level III. Guest professor from universities in the United States, South America, Spain and Italy. Founder and Academic Coordinator of the Master's and Doctorate in Education for Peace and School Coexistence in Mexico . Researcher-Professor of CIEAP, Autonomous University of the State of Mexico. Email: forerosandoval@gmail.com

*** Political scientist from the University of Tolima. Master's degree in political sociology from the "Instituto de Investigaciones Dr. José Maria Luis Mora", and doctoral candidate in social and political sciences from the Universidad Iberoamericana (Mexico). Political analyst and columnist for the newspaper "El Nuevo Día" (Colombia) and Rebelión.org (Spain). E-mail: caperafigueroa@gmail.comhttp://josecaperafigueroa.blogspot.mx/ 
Dilemmas and advances in post-conflict in colombia: a look from the subaltern perspective of peace $(s)$ in the territories

Keywords: Peace, Colombia, Subalternity, Decoloniality, Territories, Democracy.

\section{Dilemas y avances de post-conflicto en Colombia: Una mirada a la perspectiva subalterna de la paz en el territorio}

\section{RESUMEN}

El surgimiento de la construcción de una cultura popular, basada en el imperativo ético-político que vincula las demandas, necesidades y luchas de los que están abajo, constituye un aspecto que configura la dinámica de la reexistencia de los grupos sociales en sus diferentes realidades. Como reflejo de esto, está el proceso de paz firmado entre el grupo / partido guerrillero Farc-Ep y el gobierno colombiano. Así, el objetivo del siguiente artículo es realizar una discusión teóricoconceptual sobre los dilemas y avances que coexisten en el posconflicto colombiano, desde una perspectiva subalterna de paz (ces) en los territorios, teniendo en cuenta las propuestas teóricas de estudiosos de la paz como Alonso (2013); Márquez Fernández, Á. (2018a), quienes consideran la necesidad de cuestionar desde una perspectiva crítica la dinámica de la paz (s), creada en los territorios. La metodología utilizada fue la investigación colaborativa y el análisis crítico del discurso (Sandoval, 2016a), que parte de generar un diálogo intersubjetivo y horizontal entre el investigador y los grupos sociales. La conclusión fundamental de la investigación fue la necesidad de reconocer la praxis del sujeto y su ética política en términos de la construcción de laboratorios, espacios y territorios de paz desde y con los de abajo, que dan peso a la lógica de la violencia promovida y ejercida por los grupos hegemónicos. en las regiones

Palabras clave: Paz, Colombia, subalternabilidad, decolonialidad, territorios, democracia.

\section{Introduction}

The need to take on the challenges aimed at building social relationships based on dialogue, deliberation and the participation of the subjects in the public sphere, constitutes a point of enunciation that allows the emergence of intersubjective processes assumed from feeling, the being and the praxis of the actors in their daily spaces of existence. The processes of mobilization, struggle and resistance assumed by the communities and peoples in the territories, symbolizes a reflection of an anti-systemic logic that breaks into the modern and closed order of the monolithic institutions, in charge of the hegemonic groups that administer the private political power.

The slogans prepared by the groups below, in the framework of the defense of life, territory and peace in the communities, are established as a reference point for assuming an ethical - political commitment based on the construction of democratic processes from the praxis of the actors within a given and ethical political space. The task of opting for socio-political means focused on questioning the private and closed structures of the hegemonic groups personifies a field charged with debating and assuming a position of liberation of the subject in the public sphere. 
In this way, the configuration of collective actions framed in the construction of bridges that serve as input for the socio-cultural fabric of the communities, are assimilated as a becoming by seizing "other" narratives that have the ability to break orders, models and pre-established schemes by the modern / colonial imaginary of the elites in the territories. Therefore, the need to assume a critical-proactive stance in the face of its immediate context, awakens the emergence of deploying a praxis committed to the causes, demands and needs of those below.

The processes of social mobilization and resistance actions, carried out in the last decades of the twentieth century and the beginning of the twenty-first, promoted by groups, groups, associations and social movements of character: ethnic, rural, urban and popular, constitute a point of enunciation in the framework of thinking about a scenario of conflict resolution, supported by the praxis and dialogue of the actors in relation to civil society and the State.

Precisely, the turbulent times that we live are the reflection of the civilizational crisis, which sustains its capacity for violence, extermination and dispossession over the territories according to the need for transnational capital, and the colonial interests of the hegemonic groups (Alonso, 2013).

Peace being a long-term socio-cultural construction process, symbolizes the opportunity to overcome differences from the condition of otherness, builds on the recognition, respect and deliberation of their emotions, desires, fears and reasons, this reflects the interest in creating scenarios that serve as platforms for the resolution of various problematic situations of the subject in their collective daily life. However, the rationality of hegemonic groups is based on the re-production of violence through the use of means, channels and spaces of rational, economic, political and cultural domination (Fontan, 2013).

Indeed, the criticism made by Latin American thinkers such as Alonso (2013), and Márquez-Fernández (2018a), which express the need to promote a re-configuration of thinking in the region, focused on building an open and horizontal dialogue between the subjects with its social reality, at the same time, it involves going beyond the modern / colonial canons of schools, centers and traditional knowledge paradigms. On the contrary, it is about betting on a reading of the problems, experiences and resistance of movements / communities from the inter-subjective dimension and the praxis of liberation in charge of the subject in the constitution of peace.

The importance of conceiving the construction of peace as a challenge that involves the different social actors of a male / female territory, who assume an ethical commitment based on the principles of respect, solidarity and pacification of differences, so , consists in overcoming the modern notion of the "absence of violence" to make the leap, to the logic of assuming the transformation of the circumstances that mediate the realization of the subject's praxis in their daily lives (Márquez-Fernández, 2018b).

Thus, the purpose of this paper is to conduct a theoretical-conceptual discussion about the dilemmas and advances that coexist in the Colombian post-conflict, based on a subaltern perspective of peace (s) in the territories. Who involves, recognize the praxis of the subject and its political ethos in terms of building laboratories, spaces and territories of peace from and with those below, that give weight to the logic of violence promoted and exerted by the hegemonic groups in the regions. 
Dilemmas and advances in post-conflict in colombia: a look from the subaltern perspective of peace $(s)$ in the territories

\section{Epistemic approach to studies of subaltern peace (s)}

Peace studies throughout history have been conceived as a field of reflection for the social sciences, and particularly for political science. The ability to articulate narratives oriented to explain the phenomena that affect conflicts, problems, wars and violence in the different sociocultural media / spaces, represents an analytical corpus focused on investigating social, political, economic and cultural issues between the nation, the State and citizenship

The configuration of the nation-state as an invention of modernity, based on the instrumental rationality of hegemonic groups, responds to the ability to unite social sectors and generate internal / external forms of exclusion. Being a reason, it contributes to the constitution of structural conflicts throughout its consolidation. Therefore, the construction of the State as that set of modern / colonial institutions, at the service of the demands of private capital and the dynamics of accumulation by dispossession that affects pacification in the territories (Wallerstein, 2005).

Situations such as armed, physical, symbolic and political violence along with the dispossession of common goods are part of the reality in which communities co-exist, thus becoming a point of reflection that allows us to examine the importance of betting on a temporal I spatial platform where the deliberation of ideas and open dialogue is an exercise that allows the resolution of conflicts through peaceful and non-violent means, which denotes the possibility of betting on democratic, fair and defenders of dignity societies Human and democratic peace.

The classical theoretical perspective of peace studies, developed by Fisas (1978), and Guzmán (2000), mention that peace means that process of overcoming / absence of conflicts through the participation of the State and civil society in a vertical dimension, which proves to be a line conception of conceiving peace as a negative / positive state of conflict in which the participation of the individual is measured in the ability to channel / solve problems through the traditional exercise of government institutions.

At the same time, aspects such as culture, education, ideology and socio-cultural relations influence the assertive capacity to assume a process of transformation of the structural problems that exist in warlike, guerrilla and violent scenarios among others. As it demonstrates, the logic of conceiving peace from a socio-political dimension where the action of the subject is plunged under the monolithic structures of institutional power.

This perspective of conceiving peace as that trinomial: citizenship, civil society and the State, represents a modern vision in this field of study. Also, the speeches from approaches such as positive, negative peace, pacification, non-violence, civil resistance and the culture of peace among others, are a sample of classical paradigms from a Eurocentric language of knowledge (Sandoval, 2016b). For this reason, these scientific productions respond to a model of functional knowledge to the demands of the hegemonic groups.

The conception of modern / colonial peace studies has to do with that current of discourses that conceive the peace as a transnational industry of knowledge, of capital and an instrument of manipulation on the struggles of popular groups, since it serves as an institutional platform where the means of coercion / submission of the State, passes to a level of government "consensus" by pre-existing forces in the public sphere (Zibechi, 2019a).

The geopolitical position seen from the temporal, spatial and scalar logic reflects the capacity of interference that economic groups, international sectors and private agencies have, which make use of their possibility of intervening in the spaces of popular powers in charge of 
the groups and actors below. At the same time, the game of political-bureaucratic interests reflects the role that the hegemonic actors of the north assume over the re-existence and community demands of the subjects in their diverse daily spaces of socio-cultural coexistence in the south-south.

The sense of recognizing that there are other perspectives on peace studies, which are founded in our America and particularly in the countries of the South-Global, symbolizes an epistemic field under construction, since it poses the need to renew the theoretical-conceptual discussions about approaches / paradigms, to give way to an open and horizontal perspective where the experience of the subjects and the ethical-political praxis of the communities in the territories, becomes a link that starts by questioning the closed structures, traditional and monolithic of the State (Márquez Fernández, 2018a).

The discourse of subaltern peace and democratic peace has to do with the possibility of influencing concretely in the face of complex situations that manifest a scenario of violence, conflicts and long-range problems in the public sphere. The condition of rethinking peace as a topic of social research, based on the commitment to the causes of the groups below, is instituted in an alternative process typical of southern epistemologies, given that it legitimizes the transformative praxis of the subject and coherence of its action on the most vulnerable groups of our time (Zibechi, 2019b).

In turn, it is configured as a counter-hegemonic bet because it assumes an open and intercultural dialogue, which manages to question and propose new routes within the framework of diversity and the coexistence of knowledge in which the subject and communities live together. A particular territory. This situation reflects the opportunity to make a leap towards a type of science oriented to the co-working and transforming work the everyday spaces typical of the social reality of communities.

As noted, Sandoval (2016a) and Cruz (2018), in proposing the existence of a Latin American perspective of peace studies, which does not start from ignorance but from the rigorous questioning about Eurocentrates theories, since they assume a position based on the feeling of the actors, communities and social, cultural, ethnic and popular movements gestated in the Global South. Part of this theoretical dynamic is articulated with the dimension of the subalternity of peace, as it is an approach that allows questioning the hegemonic state and modern civil society, since they do not know and make invisible the feelings and demands of the subaltern groups in the region

The theoretical sense to promote this perspective of decolonial critical thinking from the perspective of peace, symbolizes an epistemic field of dispute that aims to make a radical critique of modern / colonial paradigms in this field of research, giving way to an alternative way that articulates horizontally, the subject's praxis, the resistance of the communities and the popular collective actions of the people based on the construction of peace in the territories.

\section{Critical narrative about the Colombian peace process}

The symbolic advance of peace in Colombia seems to be a paradigmatic dilemma. Let's start by understanding the complexity of the signing of the peace agreement between the government of Juan Manuel Santos I-II with the FARC guerrilla group. In this scenario, it is possible to appreciate the dilemma that implies carrying out a negotiation and pacification process between the armed actors with the civil society, taking into account the weak institutional 
Dilemmas and advances in post-conflict in colombia: a look from the subaltern perspective of peace $(s)$ in the territories

capacity of the government against the application of legal-political systems in function of the points agreed between the different sectors in the scenario of the negotiations.

After 50 years of armed conflict that has left multiple sequels in the social groups below, due to war actions and the government response that has put various actors in check, such as indigenous peoples, blacks, women, victims, the displaced and the peasants among others. Part of this situation, reveals the urgency to bet on a series of dialogues that would allow finding a peaceful, alternative and democratic exit in procedural terms, which led to the signing of a peace agreement in Havana (Cuba).

However, the signing of the peace agreement does not represent a closure of the conflict, but rather that allowed actors such as: FARC dissidents, paramilitaries and criminal gangs, among others, to serve as violent groups aimed at strengthening land dispossession, since they are functional to the interests of both left and right-wing elites, the systematic murder of the social leaders and the weakening of the social processes of those below. At the same time, it is possible to see a geopolitical interest on the part of the northern countries, associated with finding in the peace process a private transnational investment niche of the neoliberal model within the territories: the projects complexes of mega mining, land privatization, drug trafficking networks and the institutional weakness of the State, because it demonstrates the ability to guarantee the pre-agreed bases with the Farc- Ep and some social groups in the most vulnerable regions of the nation (Sandoval \& Capera, 2018).

The current condition facing Colombian society in the face of the peace process is a weak agreement with a feeble base that allows it to be modulated by the means, networks and interests of the hegemonic groups, leaving aside the effective participation of the popular classes. In the territories on the contrary, a scenario is appreciated without the minimum guarantees for the exercise of a participatory, popular and community democracy that serves as an input for the democratization of peace, being the reflection of a neoliberal model of peace that currently preexists in Colombia, which is based on violence, disqualification of the adversary and nonguarantee in terms of repetition of events similar to those that occurred in the long-term armed conflict in the country.

The ambiguity of the Farc- Ep between being a guerrilla group and taking a leap as a political party / organization, was a factor that allowed them to enter the institutional public sphere with fragility and contradictions in the political-electoral system, was established as an antecedent that demonstrates the structural non-representation of the party with its members / grassroots militants. Since the experience around peace agreements at the global level, reflect the nonexistence of real mechanisms that allow the effective, broad and democratic participation.

The situation of the FARC political party is not far from such an analysis in terms of representation and inclusion of legitimacy routes that establish links in common, through a language that serves as a scheme of social and horizontal interaction. At the same time, the critical situation that social, political, union and community leaders coexist in the country, becomes a factor that makes it impossible to effectively execute a process of pacification and democratization from and with the subaltern actors in the territories.

In this way, it is possible to recognize certain dilemmas and advances of the Colombian post-conflict:

1. The signing of the peace process is not a reflection of the country's territorial and democratic pacification. 
2. The few guarantees to recognize and offer material and immaterial conditions to networks, media, groups, groups and spaces among others, oriented to serve as individual or group actors, those who contribute with inputs in the construction of peace, truths and reconciliation among the social groups victims / perpetrators of the armed conflict.

3. The political-institutional inconsistencies on the part of the hegemonic groups about the demands of the subaltern actors in the territories. It can be seen that the peace process develops the almost hidden panorama of violence, dispossession and socio-environmental, popular conflicts, the privatization of territories and political corruption that affects the good living of communities.

Thus, the current peace process in Colombia faces challenges that are necessary to think of a popular project with the most excluded social groups in the public sphere. This becomes a series of opportunities to rethink democracy, institutions and formal and informal spaces that allow the participation, action and praxis of the various actors in the framework of the construction of another reality in the country.

\section{In conclusion}

The post-conflict in Colombia, symbolizes a complex field of crisis, opportunity and hope that invites different sectors, actors and movements to build another multicultural conception of peace, which has as its principle the horizontal participation and from below, giving weight to the bureaucratic / institutional logic of modernity / coloniality within the framework of the classical vision of statist peace.

The ethical - political responsibility for assuming peace as a socio-cultural process below, implies a turn to the modern conception of the pacification / resolution of conflicts from the rationality of the State, on the contrary, it consists of a commitment to involve actors from their human condition who manage to question and reflect on the environmental, social, political, religious, spiritual and cultural dimensions that constitute the construction of peace in the territories.

For this reason, the action of questioning the linear and governmental models of peace from elites and hegemonic groups turns out to be a decolonizing commitment that serves as input to generate cracks to the logic of a type of neoliberal peace, such as the Colombian, given way to the constitution of peace within the framework of dialogue, horizontality and participation in a substantive / popular democracy of the actors in their diverse daily spaces.

Ultimately, thinking about the Colombian post-conflict could be a scenario that allows for a liberating practice from below, being an aspect that is contrary to the colonial, closed and traditional postulates of those above. Since it intends, to generate a collective imaginary that motivates / encourages the participation, deliberation and construction of other possible, necessary and urgent worlds that weigh the wave of systemic violence, in charge of the interests of the hegemonic groups against the feel of the peace by subaltern actors in the territories.

\section{Bibliography References}

Alonso, Jorge. (2013). Repensar los movimientos sociales. Centro de Investigaciones y Estudios Superiores en Antropología Social - CIESAS. México 
Cruz, Juan Daniel. (2018). Los estudios de paz latinoamericanos en la encrucijada Producir o reproducir, una mirada desde las epistemologías del Sur. Revista CoPaLa. Año 3, número 5, México.(Pp. 9-21.)

Fisas, Vicenç. (1978). Introducción al estudio de la paz y de los conflictos. Lerna. España. Fontan, Victoria (2013). Descolonización de la Paz. Sello editorial Javeriana. Colombia.

Guzmán, Vincent. (2000). Saber hacer las paces. Epistemologías de los estudios para la paz. Convergencia Revista de Ciencias Sociales, (23), Venezuela (Pp. 49-96)

Márquez Fernández, Álvaro. (2018a). Democracia sub-alterna y estado hegemónico. crítica política desde américa latina/ diálogo abierto con Álvaro B. Márquez-Fernández. El Pregonero- Elaleph.com S.R.L. Argentina

Márquez-Fernández, Álvaro. (2018b). The role of political construction of intercultural praxis. Revista FAIA -Vol. 7, No 31 (2018): Homenaje a Aníbal Quijano, Argentina. (Pp.1-14)

Sandoval, Eduardo. (2016a). Educación para la paz integral - Memoria, interculturalidad y decolonialidad. ARFO Editores e Impresores LTDA. Colombia.

Sandoval, Eduardo. (2016b). Indigenous Zapatista education for peace and non-violence. Espacio Abierto, 25(1). Venezuela. (Pp.23-36)

Sandoval, Eduardo., \& Capera, J. (2018). El movimiento indígena colombiano y su relación con el giro decolonial en América Latina. Revista Ratio Juris Vol. 13 N. ${ }^{\circ} 27$ - UNAULA. Colombia (Pp.145-172)

Wallerstein, Immanuel. Maurice. (2005). La crisis estructural del capitalismo. Centro de Estudios, Información y Documentación" Immanuel Wallerstein" - Los libros de la contrahistoria. Desde Abajo. Colombia

Zibechi, Raúl. (2019a). Estados mafiosos y poder político. Extraído de: https://www.jornada.com.mx/2019/03/29/opinion/018a1pol .Consulta 2019/04/29

Zibechi, Raúl. (2019b). Los arroyos cuando bajan. Los desafíos del zapatismo. ZambraBalandere. España. 